\title{
Allelopathic Action of Parthenium and its Rhizospheric SoIl on Maize AS INFluenced By GRowing Conditions ${ }^{1}$
}

\author{
Efeito Alelopático de Parthenium, e de seu Solo Rizosférico no Milho em Função de Condições \\ de Crescimento
}

\author{
SAFDAR, M.E. ${ }^{2}$, TANVEER, A. ${ }^{2}$, KHALIQ, A. $^{2}$, and NAEEM, M.S. ${ }^{2}$
}

\begin{abstract}
Biosynthesis and subsequent release of allelochemicals by a plant into the environment is supposed to be influenced by its growing conditions. To ascertain what will be the allelopathic action of plant parts and rhizospheric soils of parthenium (Parthenium hysterophorus) growing at various farm locations with varied growing conditions, germination and seedling growth of maize hybrid (DK 6142) were assayed by sowing its seeds in petri plates lined with filter paper and pots filled with soil. Minimum germination percentage $(30.0 \%)$, germination index (2.01), germination energy (36.3), seedling length $(3.3 \mathrm{~cm})$, seedling biomass $(10 \mathrm{mg})$ and seedling vigor index (99.0) of maize were observed in leaf extract followed by fruit and whole plant extracts of parthenium growing near the field border. Rhizospheric soil collected underneath parthenium growing near a water channel caused maximum reductions in germination index (30.8\%), germination energy $(40.6 \%)$, seedling length $(32.6 \%)$, seedling biomass $(35.1 \%)$ and seedling vigor index $(34.3 \%)$ of maize compared with that soil without any vegetation. Phytotoxic inhibitory effects of both parthenium plant and rhizospheric soil were more pronounced on maize root than its shoot growth. The higher suppressive action against germination and seedling growth of maize was probably due to higher total phenolic concentrations (6678.2 and $\left.2549.0 \mathrm{mg} \mathrm{L}^{-1}\right)$ and presence of phenolic compounds viz., gallic, caffeic, 4-hydroxy-3-methoxy benzoic, p-coumaric and m-coumaric acids; and ferulic, vanillic, syringic and $\mathrm{m}$-coumaric acids in aqueous leaf extract of parthenium uprooted near the field border and its rhizospheric soil collected near a water channel, respectively.
\end{abstract}

Keywords: allelopathy, Parthenium hysterophorus, plant bioassay, soil bioassay, Zea mays, phenolic compounds.

RESUMO - A biossintese e subsequente liberação de aleloquímicos por uma planta no ambiente é supostamente influenciada pelas condições de crescimento. Para aferir o efeito alelopático de partes das plantas, bem como do solo rizosférico de losna-branca (Parthenium hysterophorus) crescendo em diferentes pontos de fazendas sob distintas condições na germinação e crescimento de plântulas de milho híbrido da variedade DK 6142, um experimento foi instalado em ambiente controlado, com as sementes de milho sendo semeadas em placas de Petri sobre papel-filtro, assim como em baldes contendo substrato. Os menores valores para germinação (30,0\%), indice de germinação (2,01), vigor de germinação (36,3), comprimento da plântula $(3,3 \mathrm{~cm})$, biomassa da plântula (10 mg) e indice de vigor da plântula $(99,0)$ de milho foram registrados sob aplicação de extrato da folha, seguido por extrato do fruto e da planta inteira de losna-branca crescendo em Terras Altas. O solo rizosférico coletado sob plantas dessa espécie crescendo próximo a canais de água provocou maior redução no indice de germinação (30,8\%), vigor de germinação (40,6\%), comprimento da plântula (32,6\%), biomassa da plântula $(35,1 \%)$ e indice de vigor da plântula $(34,3 \%)$ de milho, comparado às plantas cultivadas em solo coletado em área sem vegetação. Os efeitos fitotóxicos inibitórios tanto da losna-branca como de seu solo rizosférico foram mais pronunciados nas raizes do milho, em comparação com a parte aérea. O maior efeito supressivo na germinação e crescimento da plântula de milho deveu-se provavelmente à maior concentração de fenóis totais $\left(6.678,2\right.$ e 2.549,0 mg $\mathrm{L}^{-1}$ ) e à presença de compostos fenólicos, como ácidos gálico, cafeico, 4 hidroxy 3 methoxy benzoico, $p$ cumárico e $m$

Recebido para publicação em 3.11.2013 e aprovado em 3.2.2014.

University of Agriculture, Faisalabad, Pakistan, <ehsansafdar2002@gmail.com>.

Planta Daninha, Viçosa-MG, v. 32, n. 2, p. 243-253, 2014 
cumárico, e de ácido ferúlico, vanílico, siringico e $m$ cumárico no extrato aquoso das folhas de plantas coletadas em Terras Altas e de seu solo rizosférico coletado próximo a canais de água, respectivamente.

Palavras-chave: alelopatia, Parthenium hysterophorus, bioensaio com planta, bioensaio com solo, Zea mays, compostos fenólicos.

\section{INTRODUCTION}

Invasive weeds are exotic pest plants that are introduced to a new ecosystem and are potentially considered hazardous to it and cause economic, environmental or health problems (ISAC, 2006). Allelopathic interference is considered one of the prospective tools in successful incursion of invasive weeds in any new region of the world. Allelopathy helps to dominate one plant species in its environment by disrupting the growth of other plants via release of chemical substances called allelochemicals (Rice, 1979) which are the secondary plant metabolites produced as offshoot of primary metabolic processes in all parts of the plant, i.e., roots, shoots, leaves, seeds, and flowers (Zimdahl, 2007). The allelochemical production within plants is largely affected by its growing conditions including both soil and climate (Peng et al., 2004), their greater amounts have been shown under nutrient, water and high light stress conditions (Putnam, 1983).

The mode of entry of allelochemicals into the environment plays an important role in the expression of their phytotoxic activity (Zimdahl, 2007). These may be released as leachates from plant foliage or litter, volatiles from aerial plant parts, exudates or sloughed out tissue from roots, or decomposition products from dead plant remains (Steeghs et al., 2004). Root exudation is considered the main way by which allelochemicals are added into the rhizosphere (Kobayashi, 2004). It is evident from the fact that $30 \%$ of plant's photosynthates are consumed in the production of root exudates, which affect the local soil environment (Bertin et al., 2003). Synthesis and release of allelochemicals from root cells into the soil are linked with the cellular transport system, therefore depending on localized soil conditions, especially stress factors (Weston et al., 2012). The allelopathic phenomenon in the soil is further complicated by soil factors such as mobility; the movement and uptake of allelochemicals in the soil are strongly linked with soil physical and bio-chemical properties, as well as soil moisture conditions, which in turn affect their adsorption and degradation (Kobayashi, 2004). Vidal et al. (1998) while comparing pot-based soil bioassay from petridish based filter paper bioassay, noted that 10 to $40 \%$ of phenolic compounds applied to the soil were tightly adsorbed to soil colloidal complex, resulting in their overall reduced phytotoxic activity.

Parthenium hysterophorus, a well-known invasive weed belongs to the Asteraceae family. It is summer annual or semi-perennial in its growth habit. This weed has been included in the global invasive species database (GISD, 2010). About 30 countries, including Pakistan, have been invaded by parthenium, were it has become destructive to agro-ecosystems (Nigatu et al., 2010; Riaz \& Javed, 2010). The successful invasion of this weed is mainly attributed to its allelopathic potential (Kohli \& Rani, 1994) which is due to parthenin and coronopilin, the two important sesquiterpene lactones present in parthenium. In addition, caffeic, vanillic, ferulic, chlorogenic and anisic acids are phenolics of phytotoxic nature released by various plant parts of parthenium in varied concentrations (Batish et al., 2007; Reinhardt et al., 2009). Other groups of allelochemicals found in the aerial parts of parthenium include tannins, saponins, cardiac glycosides, terpenoids and steroids (Ambiye \& Golatkar, 2010).

The phytotoxic inhibition of germination and growth of maize and other crops by allelochemicals produced from various plant parts of parthenium have been well documented (Wakjira et al., 2005; Maharjan et al., 2007; Marwat et al., 2008; Dhole et al., 2011; Khan et al., 2012; Devi \& Dutta, 2012). 
However, nothing is known about whether the suppressive action caused by parthenium and its rhizospheric soil is modified by growing conditions of this weed. Laboratory bioassay studies were therefore planned to assess the allelopathic effect of various plant parts and rhizospheric soils of parthenium growing at different farm locations with varied growing conditions against maize crop.

\section{MATERIAL AND METHODS}

Plant and soil bioassay studies were conducted in Weed Science Laboratory, Department of Agronomy, University of Agriculture, Faisalabad, Pakistan during 2011 and 2012. Aqueous extracts of root, stem, leaf, fruit and whole plant of parthenium and its rhizospheric soils collected from various farm locations were employed to compare their allelopathic effect against germination and seedling growth of maize. During each year, parthenium plants at their maturity were uprooted from various farm locations and soils beneath them were collected. Farm locations include near a water channel, at the field border and at a water pond, which represent different growing conditions. Plants were subjected to initial drying at room temperature and then oven-dried at $70{ }^{\circ} \mathrm{C}$ for 48 hours. The dried plants were separated into roots, stems, leaves and fruits and their 5\% $(\mathrm{w} / \mathrm{v})$ aqueous extracts were prepared by soaking them in distilled water for a period of 24 hours at room temperature $\left(30^{\circ} \mathrm{C} \pm 4\right)$ with ratio of 1:20 w/v (Hussain \& Gadoon, 1981). The final extracts used in study were obtained by filtering the mixture through 10 and 60 mesh sieves. Soils from various sites were also dried at room temperature and sieved before being used for soil-bioassays. In plant bioassay, 10 seeds of maize were sown in each petri plate, supplied with $8 \mathrm{~mL}$ of aqueous extracts of different plant parts of parthenium collected from various farm locations and then sealed with parafilm. Distilled water was applied to the control treatment. Each treatment was replicated four times and the experiment was laid out in completely randomized design with factorial arrangement. In the soil bioassay, 10 seeds of maize were sown in plastic pots of $11 \mathrm{~cm}$ diameter and $5 \mathrm{~cm}$ depth, each filled with the $350 \mathrm{~g}$ soil of each location. Soil from the weed free site was used as control and treatments were arranged in completely randomized design with four replications. Initially, $100 \mathrm{~mL}$ distilled water was added to each pot and during the course of experiment, the required quantity of distilled water was supplied to each pot when needed. In both experiments, the maize hybrid DK 6142 was used. During the course of experiments in both years, minimum and maximum temperatures ranged from 29 to $32{ }^{\circ} \mathrm{C}$ and 31 to $37^{\circ} \mathrm{C}$, respectively whereas the photoperiod was 13 hours.

Plant and soil aqueous extracts were tested for their biochemical characteristics. Soil aqueous extracts were prepared from the soil of each farm location by soaking $5 \mathrm{~g}$ soil in $50 \mathrm{~mL}$ distilled water for 24 hours. The plant and soil extracts were then filtered through micro syringe filters. The $\mathrm{pH}$ and EC of each soil extract were determined with $\mathrm{pH}$ meter (JENWAY $3510 \mathrm{pH}$ Meter) and EC meter (JENWAY 3510 conductivity Meter), respectively. Total soluble phenolics were determined as described by Randhir \& Shetty (2005) and were expressed as gallic acid equivalents. For identification and quantification of their suspected phytotoxins, aqueous extracts were chemically analyzed on Shimadzu HPLC system (Model SCL-10A, Tokyo, Japan). The peaks were detected by UV detector. Standards of suspected phytotoxins (Aldrich, St Louis, USA) were run similarly for their identification and quantification. Concentration (Conc.) of each isolated compound was determined by the following equation: Conc. $(\mathrm{ppm})=$ Area of the sample/ Area of the standar $\times$ Conc. of the standard $x$ Dilution factor.

Biochemical characteristics of aqueous extracts of parthenium plant parts and its rhizospheric soils from various farm locations and their phenolic compositions are presented in Tables 1 and 2.

During both years, in plant and soil bioassay experiments, a daily germination count was made for a period of 7 days. After germination completion, root and shoot lengths of seedlings were measured. Seedlings were separated into roots and shoots and weighed after oven drying at $65^{\circ} \mathrm{C}$ for 24 hours. Germination count data were used to 
Table 1 - Biochemical characteristics of aqueous extracts of parthenium plant parts and rhizospheric soils from various farm locations

\begin{tabular}{|c|c|c|c|c|c|}
\hline \multicolumn{6}{|c|}{ Aqueous extracts $(5 \% \mathrm{w} / \mathrm{v})$ of parthenium plant parts } \\
\hline Location & Plant Part & $\mathrm{pH}$ & $\mathrm{EC}\left(\mathrm{dS} \mathrm{m} \mathrm{m}^{-1}\right)$ & $\begin{array}{l}\text { Osmotic potential } \\
\qquad(-\mathrm{MPa})\end{array}$ & $\begin{array}{l}\text { Total phenolic } \\
\text { concentration } \\
\left(\mathrm{mg} \mathrm{L}^{-1}\right)\end{array}$ \\
\hline \multirow{5}{*}{$\begin{array}{l}\text { Near a water } \\
\text { channel }\end{array}$} & Fruit & 7.8 & 5.97 & 0.21 & 4325.3 \\
\hline & Stem & 6.8 & 8.64 & 0.31 & 3633.2 \\
\hline & Leaf & 7.6 & 8.34 & 0.30 & 4256.1 \\
\hline & Root & 4.9 & 2.43 & 0.09 & 3194.9 \\
\hline & Whole plant & 6.8 & 8.00 & 0.29 & 2318.3 \\
\hline \multirow{5}{*}{$\begin{array}{l}\text { Near the } \mathrm{f} \text { ield } \\
\text { border }\end{array}$} & Fruit & 7.9 & 7.14 & 0.26 & 6170.7 \\
\hline & Stem & 7.4 & 9.53 & 0.34 & 2410.6 \\
\hline & Leaf & 7.6 & 9.89 & 0.36 & 6678.2 \\
\hline & Root & 8.0 & 3.56 & 0.13 & 1972.3 \\
\hline & Whole plant & 7.7 & 7.10 & 0.26 & 3218.0 \\
\hline \multirow{5}{*}{$\begin{array}{l}\text { Near a water } \\
\text { pond }\end{array}$} & Fruit & 7.1 & 6.37 & 0.23 & 5178.8 \\
\hline & Stem & 7.4 & 9.90 & 0.36 & 2895.0 \\
\hline & Leaf & 7.8 & 9.96 & 0.36 & 5155.7 \\
\hline & Root & 5.6 & 2.99 & 0.11 & 1949.3 \\
\hline & Whole plant & 7.5 & 9.16 & 0.33 & 4071.5 \\
\hline \multicolumn{6}{|c|}{ Aqueous extracts $(10 \% \mathrm{w} / \mathrm{v})$ of parthenium rhizospheric soil } \\
\hline \multicolumn{2}{|c|}{ Near a water channel } & 8.4 & 0.14 & 0.005 & 2549.0 \\
\hline \multicolumn{2}{|c|}{ Near the field border } & 8.3 & 0.14 & 0.005 & 2502.9 \\
\hline \multicolumn{2}{|c|}{ Near a water pond } & 8.1 & 0.13 & 0.005 & 2387.5 \\
\hline \multicolumn{2}{|l|}{ Weed free site } & 8.5 & 0.12 & 0.004 & 2087.7 \\
\hline
\end{tabular}

calculate various seed germination and vigor parameters as detailed below:

Germination percentage (GP) was calculated by the following formula:

$$
\mathrm{GP}=\left[\mathrm{N}_{\mathrm{T}} \times 100\right] / \mathrm{N}
$$

where $\mathrm{N}_{\mathrm{T}}$ : proportion of germinated seeds in each treatment for the final measurement, and N: Number of seeds used in bioassay.

The germination index (GI) was calculated by following the formula described by Scott et al. (1984):

$$
\mathrm{GI}=\mathrm{N}_{1} / \mathrm{D}_{1}+\ldots \ldots \ldots \ldots \ldots \ldots+\mathrm{N}_{\mathrm{L}} / \mathrm{D}_{\mathrm{L}}
$$

where $\mathrm{N}_{1}$ : number of seeds germinated on $1 \mathrm{st}$ count, $\mathrm{D}_{1}$ : days to $1 \mathrm{st}$ count, $\mathrm{N}_{\mathrm{L}}$ : number of seeds germinated on last count, and $\mathrm{D}_{\mathrm{L}}$ : days to last count.

Mean germination time (MGT) was calculated by the following equation as given by MoradiDezfuli et al. (2008):

$$
\mathrm{MGT}=\Sigma \mathrm{Dn} / \Sigma \mathrm{n}
$$

where n: Number of seeds which were germinated on day D, D: Number of days counted from the beginning of germination.

Time to $50 \%$ germination $\left(\mathrm{T}_{50}\right)$ was calculated according to the following formula modified by Farooq et al. (2005):

$$
\mathrm{T}_{50}=\mathrm{t}_{\mathrm{i}}+\left\{(\mathrm{N} / 2)-\mathrm{n}_{\mathrm{i}}\right\}\left(\mathrm{t}_{\mathrm{j}}-\mathrm{t}_{\mathrm{i}}\right) / \mathrm{n}_{\mathrm{j}}-\mathrm{n}_{\mathrm{i}}
$$

where N: Final number of germination, $n_{i}, n_{j}$ : cumulative number of seeds germinated by adjacent counts at times $t_{i}$ and $t_{j}$ when $n_{i}<N /$ $2<\mathrm{n}_{\mathrm{j}}$.

Seedling vigor index (SVI) was calculated by the following formula as described by Orchard (1977):

SVI $=$ seedling length $(\mathrm{cm}) \times$ germination percentage

Germination energy (GE) was recorded on the 4 th day after planting. It is the percentage 


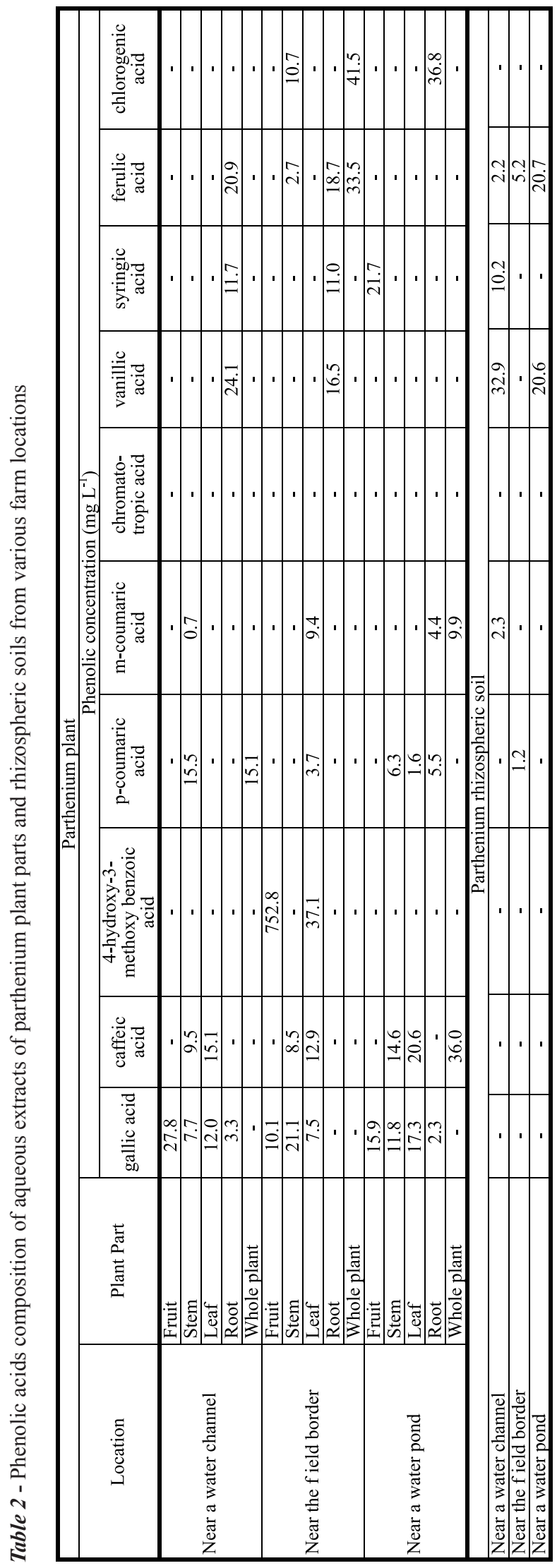

of germinating seeds 4 days after planting relative to the total number of seeds tested (Ruan et al., 2002).

Similar trend was shown by data of both years, therefore these were compiled. Average data thus obtained were analyzed statistically using Fisher's analysis of variance with the Statistix 8.1 software. Treatment means were compared on the basis of least significant difference at the $0.05(5 \%)$ probability level (Steel et al., 1996).

\section{RESULTS AND DISCUSSION}

An allelopathic study in weed science should necessarily focus germination and early seedling growth so that weed control recommendation could be made during early critical competition period (Hoffman et al., 1996). Since the last few decades, various techniques have been employed in allelopathic studies. A number of laboratory protocols have been standardized and evaluated for phytotoxic allelopathic studies. Few of these methodologies include hydroponic methods, equal-compartment-agar-method, relay seeding technique and plant-box method (Belz, 2007). These methodologies have been successfully used for the isolation of a number of phytotoxins that are secreted by plants (Wu et al., 2009). On the contrary, it becomes difficult to identify a pure allelopathic effect from resource competition effect under field conditions. Therefore, in vitro laboratory screening is mostly considered reliable, rapid and economical. However, a major drawback of these techniques is utilization of artificial substrates for germination and plant growth without involving natural substrate soil. These systems therefore cannot present a true picture of allelochemical release, soil adsorption and plant uptake, a complex rhizosphere-allelochemical-plant interaction system. Thus results obtained from laboratory allelopathic studies by using soil and filter paper as substrates may differ from each other (Inderjit \& Callaway, 2003).

Plant Bioassay: Germination percentage (GP), germination index (GI) and germination energy (GE) are directly related to germination performance of seed in terms of total number of seeds germinated, germination speed 
and germination ability under unfavorable conditions, respectively. Mean germination time (MGT) and time to $50 \%$ germination $\left(\mathrm{T}_{50}\right)$ are two important parameters of germination representing time required to complete germination. Lower values of these parameters therefore reflect higher germination performance. Data regarding various germination parameters of maize as affected by application of aqueous plant extracts of various plant parts of parthenium growing at various farm locations are presented in Table 3, which showed that significant differences exist among means of different locations, plant parts as well as their interaction. Aqueous extracts of parthenium plant parts from all three farm locations inhibited the germination and seedling growth of maize.

Comparison among various farm locations revealed that aqueous extracts of parthenium plants collected near the field border caused maximum inhibition in the germination of maize by giving minimum GP (43.3\%), GI (4.09) and GE (49.6) while longest MGT (4.06 days) and $\mathrm{T}_{50}$ (3.45 days). Among parthenium plant parts, leaf extract showed significantly lower values of GP (34.2\%) and GI (2.85) while longest MGT (4.15 days) and $\mathrm{T}_{50}$ (3.71 days) which were 60.9 and $69.5 \%$ lower while 50.8 and $21.7 \%$ higher than distilled water treated control (DWTC). However, GE did not differ significantly among various plant parts. Regarding location $\mathrm{x}$ plant part interaction, significantly lowest values of GP (30.0\%) and GI (2.01) while longest MGT (4.94 days) and $\mathrm{T}_{50}$ (4.50 days) were observed in leaf extract of parthenium growing near field border (Figure 1). Contrastingly, the highest GP $(97.5 \%)$ and GI $(9.34)$ were given by the control treatment where distilled water was applied.

Data regarding various seedling growth parameters of maize as affected by aqueous extracts of various plant parts of parthenium growing at different farm locations are presented in Table 4, which revealed that parthenium plants growing near the field border exhibited maximum inhibitory effects on maize seedlings followed by those growing near a water pond and water channel.

Table 3 - Means of germination parameters of maize as influenced by aqueous extracts of plant parts and rhizospheric soils of parthenium uprooted from various farm locations

\begin{tabular}{|c|c|c|c|c|c|c|}
\hline \multicolumn{7}{|c|}{ Parthenium plant } \\
\hline Location & GP & GI & $\mathrm{T}_{50}$ (days) & MGT (days) & $\mathrm{GE}$ & SVI \\
\hline Near a water channel & $54.2 \mathrm{a}$ & $4.40 \mathrm{ab}$ & $3.41 \mathrm{ab}$ & $4.01 \mathrm{a}$ & $67.9 \mathrm{a}$ & $894.2 \mathrm{a}$ \\
\hline Near the f ield border & $43.3 \mathrm{c}$ & $4.09 \mathrm{~b}$ & $3.45 \mathrm{a}$ & $4.06 \mathrm{a}$ & $49.6 \mathrm{~b}$ & $450.2 \mathrm{c}$ \\
\hline Near a water pond & $46.3 \mathrm{~b}$ & $5.01 \mathrm{a}$ & $3.12 \mathrm{~b}$ & $3.71 \mathrm{~b}$ & $77.7 \mathrm{a}$ & $595.7 \mathrm{~b}$ \\
\hline LSD & 2.91 & 0.68 & 0.33 & 0.21 & 11.1 & 71.3 \\
\hline \multicolumn{7}{|l|}{ Plant Part } \\
\hline DWTC & $87.5 \mathrm{a}$ & $9.34 \mathrm{a}$ & $2.46 \mathrm{~b}$ & $3.41 \mathrm{c}$ & 74.9 & $1611.2 \mathrm{a}$ \\
\hline Fruit & $40.0 \mathrm{~b}$ & $3.53 \mathrm{~b}$ & $3.38 \mathrm{a}$ & $4.06 \mathrm{ab}$ & 68.3 & $445.6 \mathrm{c}$ \\
\hline W.P & $40.8 \mathrm{~b}$ & $3.60 \mathrm{~b}$ & $3.63 \mathrm{a}$ & $4.18 \mathrm{a}$ & 62.2 & $457.1 \mathrm{c}$ \\
\hline Root & $42.5 \mathrm{~b}$ & $3.75 \mathrm{~b}$ & $3.50 \mathrm{a}$ & $3.97 \mathrm{ab}$ & 59.6 & $634.0 \mathrm{~b}$ \\
\hline Stem & $42.5 \mathrm{~b}$ & $3.91 \mathrm{~b}$ & $3.29 \mathrm{a}$ & $3.78 \mathrm{~b}$ & 67.2 & $535.5 \mathrm{bc}$ \\
\hline Leaf & $34.2 \mathrm{c}$ & $2.85 \mathrm{~b}$ & $3.71 \mathrm{a}$ & $4.15 \mathrm{a}$ & 58.3 & $196.7 \mathrm{~d}$ \\
\hline LSD & 5.04 & 1.17 & 0.58 & 0.36 & NS & 123.6 \\
\hline \multicolumn{7}{|c|}{ Parthenium rhizospheric soil } \\
\hline Near a water channel & 97.5 & $2.87 \mathrm{~b}$ & $3.79 \mathrm{a}$ & $4.04 \mathrm{a}$ & $59.45 \mathrm{~b}$ & $3749.0 \mathrm{~b}$ \\
\hline Near the f ield border & 100.0 & $4.0 \mathrm{a}$ & $2.00 \mathrm{~b}$ & $2.75 \mathrm{~b}$ & $92.50 \mathrm{a}$ & $5621.7 \mathrm{a}$ \\
\hline Near a water pond & 100.0 & $3.95 \mathrm{a}$ & $2.00 \mathrm{~b}$ & $2.80 \mathrm{~b}$ & $92.50 \mathrm{a}$ & $5441.4 \mathrm{a}$ \\
\hline Weed free soil & 100.0 & $4.15 \mathrm{a}$ & $2.00 \mathrm{~b}$ & $2.53 \mathrm{~b}$ & $100.00 \mathrm{a}$ & $5705.3 \mathrm{a}$ \\
\hline LSD & NS & 0.2641 & 1.1165 & 0.4904 & 15.801 & 684.79 \\
\hline
\end{tabular}

$\mathrm{GP}=$ germination percentage, $\mathrm{GI}=$ germination index, $\mathrm{T}_{50}=$ time to $50 \%$ germination, $\mathrm{MGT}=$ mean germination time, $\mathrm{GE}=$ germination energy, SVI = seedling vigor index, DWTC=distilled water treated control. In a column, values with different letters show significant difference $(\mathrm{P} \leq 0.05)$ as determined by least significant difference test. . NS $=$ non significant. 


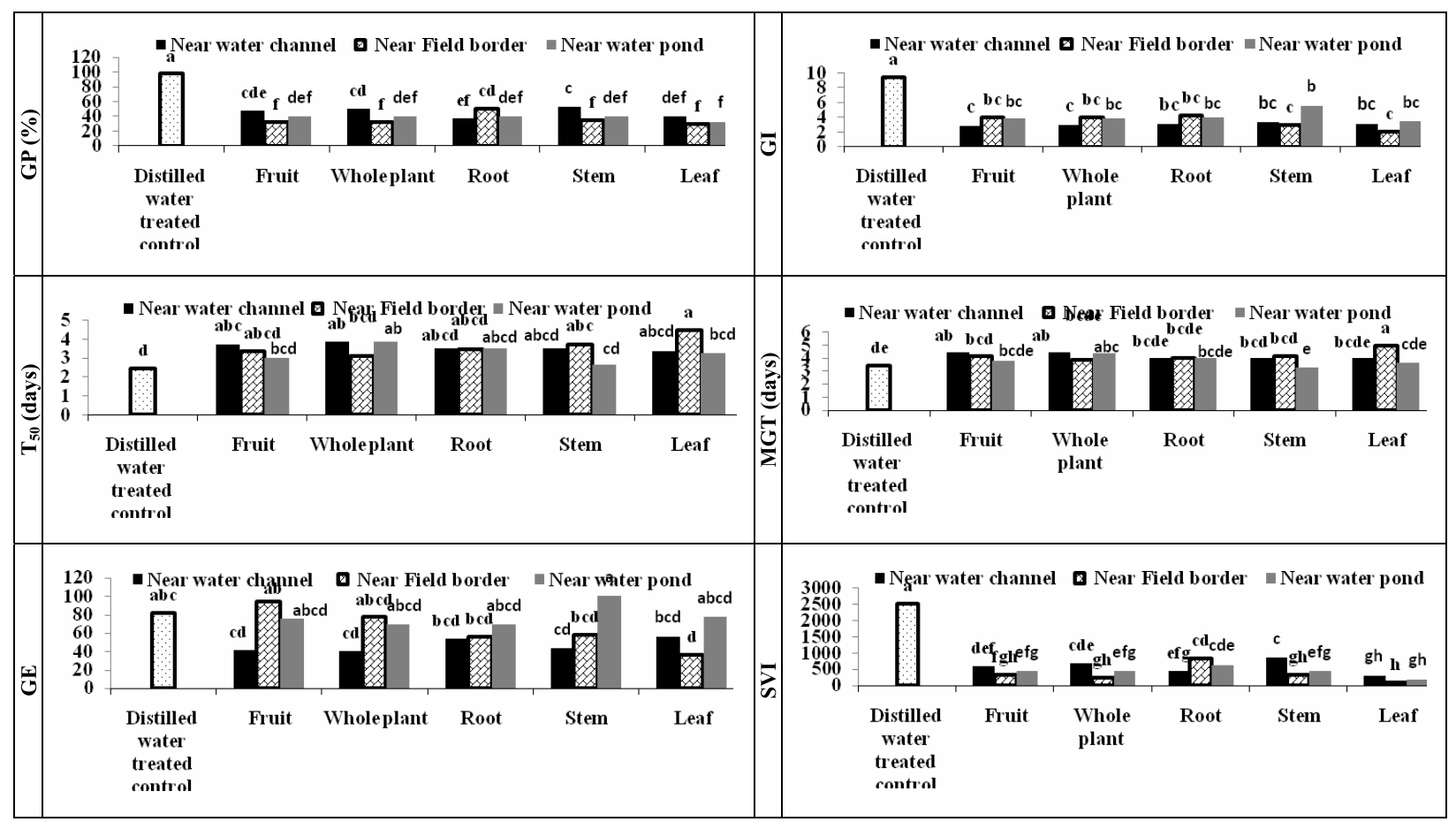

Figure 1 - Interaction means of germination parameters as influenced by aqueous extracts of plant parts of parthenium uprooted from various farm locations.

Table 4 - Means of seedling growth of maize as influenced by aqueous extracts of plant parts and rhizospheric soils of parthenium uprooted from various farm locations

\begin{tabular}{|c|c|c|c|c|c|c|}
\hline \multicolumn{7}{|c|}{ Parthenium plant } \\
\hline Location & SDW (mg) & RDW (mg) & SL (cm) & $\mathrm{RL}(\mathrm{cm})$ & $\mathrm{SDL}(\mathrm{cm})$ & SB (mg) \\
\hline Near a water channel & $58 \mathrm{a}$ & $15 \mathrm{a}$ & $12.28 \mathrm{a}$ & $2.22 \mathrm{a}$ & $14.50 \mathrm{a}$ & $73 \mathrm{a}$ \\
\hline Near the $f$ ield border & $39 \mathrm{c}$ & $10 \mathrm{c}$ & $8.31 \mathrm{c}$ & $1.28 \mathrm{~b}$ & $9.59 \mathrm{c}$ & $48 \mathrm{c}$ \\
\hline Near a water pond & $51 \mathrm{~b}$ & $12 \mathrm{~b}$ & $10.56 \mathrm{~b}$ & $1.36 \mathrm{~b}$ & $11.92 \mathrm{~b}$ & $63 \mathrm{~b}$ \\
\hline LSD & 4 & 1.4 & 0.60 & 0.47 & 0.85 & 4 \\
\hline \multicolumn{7}{|l|}{ Plant Part } \\
\hline DWTC & $69 \mathrm{a}$ & $20 \mathrm{a}$ & $15.33 \mathrm{a}$ & $2.62 \mathrm{a}$ & $17.94 \mathrm{a}$ & $89 \mathrm{a}$ \\
\hline Fruit & $52 \mathrm{~b}$ & $11 \mathrm{~b}$ & $8.93 \mathrm{~d}$ & $2.06 \mathrm{ab}$ & $10.99 \mathrm{c}$ & $62 \mathrm{c}$ \\
\hline W.P & $35 \mathrm{c}$ & $11 \mathrm{~b}$ & $10.17 \mathrm{c}$ & $0.58 \mathrm{c}$ & $10.76 \mathrm{c}$ & $46 \mathrm{~d}$ \\
\hline Root & $57 \mathrm{~b}$ & $13 \mathrm{~b}$ & $12.38 \mathrm{~b}$ & $2.31 \mathrm{ab}$ & $14.69 \mathrm{~b}$ & $71 \mathrm{~b}$ \\
\hline Stem & $55 \mathrm{~b}$ & $12 \mathrm{~b}$ & $10.39 \mathrm{c}$ & $1.69 \mathrm{~b}$ & $12.08 \mathrm{c}$ & $66 \mathrm{bc}$ \\
\hline Leaf & $29 \mathrm{c}$ & $8 \mathrm{c}$ & $5.10 \mathrm{e}$ & $0.46 \mathrm{c}$ & $5.56 \mathrm{~d}$ & $36 \mathrm{e}$ \\
\hline LSD & 0.006 & 0.003 & 1.04 & 0.81 & 1.47 & 8 \\
\hline \multicolumn{7}{|c|}{ Parthenium rhizospheric soil } \\
\hline Near a water channel & $66 \mathrm{~b}$ & $21 \mathrm{c}$ & $22.96 \mathrm{~b}$ & $15.53 \mathrm{c}$ & $38.48 \mathrm{~b}$ & $87 \mathrm{c}$ \\
\hline Near the $f$ ield border & $85 \mathrm{a}$ & $37 \mathrm{a}$ & $29.10 \mathrm{a}$ & $24.89 \mathrm{ab}$ & $56.22 \mathrm{a}$ & $124 \mathrm{ab}$ \\
\hline Near a water pond & $87 \mathrm{a}$ & $31 \mathrm{~b}$ & $30.44 \mathrm{a}$ & $23.97 \mathrm{~b}$ & $54.42 \mathrm{a}$ & $118 \mathrm{~b}$ \\
\hline Weed free soil & $95 \mathrm{a}$ & $39 \mathrm{a}$ & $32.16 \mathrm{a}$ & $27.12 \mathrm{a}$ & $57.05 \mathrm{a}$ & $134 \mathrm{a}$ \\
\hline LSD & 11 & 5 & 5.48 & 2.58 & 7.03 & 11 \\
\hline
\end{tabular}

$\mathrm{SDW}=$ shoot dry weight, $\mathrm{RDW}=$ root dry weight, $\mathrm{SL}=$ shoot length, $\mathrm{RL}=$ Root length, $\mathrm{SFW}=$ Shoot fresh weight, $\mathrm{SDL}=$ seedling length, $\mathrm{SB}=$ seedling biomass, DWTC $=$ distilled water treated control. In a column, values with different letters show significant difference $(\mathrm{P} \leq 0.05)$ as determined by least significant difference test. 
Significantly lowest shoot length $(8.31 \mathrm{~cm})$ and dry weight $(39 \mathrm{mg})$, root length $(1.28 \mathrm{~cm})$ and dry weight $(10 \mathrm{mg})$, seedling length $(9.59 \mathrm{~cm})$ and dry weight $(48 \mathrm{mg}$ ) of maize seedlings were recorded from treatment receiving aqueous extract of parthenium growing near the field border. Regarding plant parts, parthenium leaf extract showed maximum seedling growth inhibition of maize by producing significantly lower shoot length $(5.10 \mathrm{~cm})$ and dry weight $(29 \mathrm{mg})$, root length $(0.46 \mathrm{~cm})$ and dry weight $(8 \mathrm{mg})$, seedling length $(5.56 \mathrm{~cm})$ and dry weight (36 mg) in maize along with $66.7 \%$, $58 \%, 82.4 \%, 60 \%, 69 \%$ and $59.6 \%$ reductions, respectively compared with DWTC. Whole plant and fruit extracts seem to be the second most potent seedling growth inhibitors. Comparison of means of location and plant part interactions discloses that leaf extract of parthenium plant uprooted from near the field border expressed highest phytotoxic effect against seedling growth of maize (Figure 2). This treatment combination produced significantly lower shoot length $(3.0 \mathrm{~cm})$ and dry weight $(7 \mathrm{mg})$, root length $(0.30 \mathrm{~cm})$ and dry weight $(3 \mathrm{mg})$, seedling length $(3.3 \mathrm{~cm})$ and dry weight $(10 \mathrm{mg})$ with concomitant reductions of $85.8 \%, 92.1 \%, 93.8 \%, 88.5 \%, 87.3 \%$ and $91.3 \%$, respectively from DWTC. Data pertaining to seedling vigor index (SVI) which is an indicator of overall germination and seedling growth performance are given in Table 3. Among farm location means averaged across plant parts, the location near the field border resulted in maximum inhibitory effect which was followed by near a water pond and water channel. Aqueous extract from parthenium plant collected near the field border resulted in significantly lowest SVI (450.2) compared with that from near a water pond (595.7) and irrigation channel (894.2). Among plant parts, leaf extract produced significantly lowest SVI (196.7) followed by fruit (445.6) and whole plant (457.1) extracts with resultant reductions of $87.8 \%, 72.3 \%$ and $71.6 \%$ over distilled water treated control, respectively. Similarly, among locations x plant parts means, the farm location near the field border in interaction with leaf extract resulted in significantly lower SVI (99.0) indicating that leaf extract from parthenium plants growing at this location showed

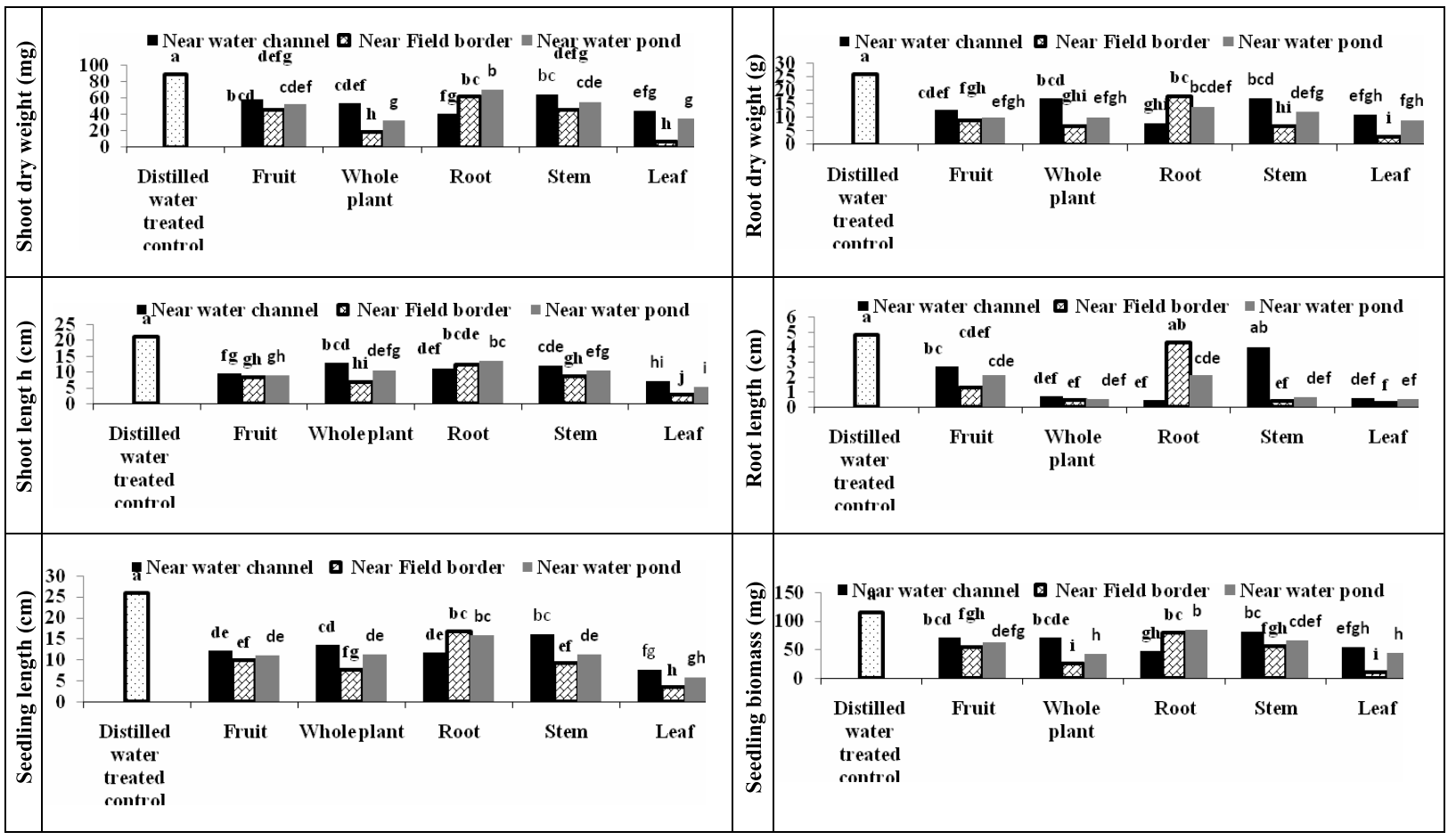

Figure 2 - Interaction means of seedling growth parameters as influenced by aqueous extracts of plant parts of parthenium uprooted from various farm locations. 
maximum inhibitory effect on maize germination and seedling growth (Figure 1).

Soil bioassay: Data relevant to germination and seedling growth of maize as influenced by parthenium rhizospheric soils from various farm locations were presented in Tables 3 and 4. Parthenium rhizospheric soil from all the three farm locations inhibited the germination and seedling growth of maize. Maximum inhibitory effects on germination and seedling growth of maize were shown by the parthenium rhizospheric soil collected near water channel which were followed by those collected near pond and field border. Statistically significantly lower GI (2.87), GE (59.5) and SVI (3749.0) whereas higher MGT (4.04 days) and $\mathrm{T}_{50}$ (3.79 days) of maize were shown by soil taken from rhizosphere of parthenium growing near water channel (Table 3). However, non-significant differences in GP were observed among parthenium infested soils from various farm locations (Table 3). On the other hand, the highest GI (4.15), GE (100.0) and SVI (5705.3) while lowest MGT (2.53 days) and $\mathrm{T}_{50}$ (2.0 days) were produced by soil without any vegetation. The seedling growth parameters also showed similar pattern as minimum values of shoot length $(22.96 \mathrm{~cm})$ and dry weight $(66 \mathrm{mg})$, root length $(15.53 \mathrm{~cm})$ and dry weight $(21 \mathrm{mg})$, seedling length $(38.5 \mathrm{~cm})$ and biomass $(87 \mathrm{mg})$ of maize were recorded in treatment where the soil from the rhizosphere of parthenium growing near a water channel was used as germination medium (Table 4).

Conclusively, parthenium plants uprooted near the field border while parthenium rhizospheric soil near a water channel exhibited the most suppressive action against maize as shown by plant and soil bioassays. Contrasting results from plant and soil bioassay have also been demonstrated by Vidal et al. (1998) who noted that germination response of Selaria faberi to applied phenolics was different on soil and petri dish bioassays due to differential allelopathic activity of various phenolics in these germination media. The main factor responsible for it was soil adsorption, which was higher for caffeic acid and catechol but lower for salicilic and ferulic acids. Seedling growth inhibition by soil amended with parthenium plant residues was also reported by Batish et al. (2002) in chickpea (Cicer arietinum) and radish (Raphanus sativus) whereas in the Brassica species (Brassica campestris, Brassica oleracea and Brassica rapa) by Singh et al. (2005). Paudel et al. (2009) observed that Parthenium hysterophorus rhizospheric soil diffusates reduced germination rate and speed in Raphanus sativus. In the present soil bioassay, maximum germination and seedling growth inhibitory effects caused by rhizospheric soil underneath parthenium growing near a water channel were probably due to higher total phenolic contents $\left(2549.0 \mathrm{mg} \mathrm{L}^{-1}\right)$ and individual phenolic concentrations i.e. $\mathrm{m}$-coumaric acid $\left(2.3 \mathrm{mg} \mathrm{L}^{-1}\right)$, vanillic acid (32.9 $\left.\mathrm{mg} \mathrm{L}^{1}\right)$, syringic acid $\left(10.2 \mathrm{mg} \mathrm{L}^{-1}\right)$ and ferulic acid $\left(2.2 \mathrm{mg} \mathrm{L}^{-1}\right)$ compared with those collected from other farm locations (Tables 1 and 2).

Among plant parts, leaf extract proved to be more phytotoxic compared with other plant parts. Fruit and whole plant extracts could be ranked at second and third position. Moreover, percent reduction in root growth was more than that in shoot growth. Previous bioassay studies have also shown the negative allelopathic effects of various plant parts of parthenium on the germination and growth of maize and other crops such as wheat, ryegrass, soybean, cotton and sorghum (Mersie \& Singh, 1987; Dhole et al., 2011; Devi \& Dutta, 2012). In most of the studies, its leaf and flower proved to be more phytotoxic than its stem and root (Wakjira et al., 2005; Marwat et al., 2008; Khan et al., 2012). Likewise, more inhibitory effects of these plant parts on root growth than shoot growth of maize, ryegrass, soybean and rice were also reported by Mersie \& Singh (1987) and Maharjan et al. (2007). In our study, the highest allelopathic activity of aqueous leaf extract of parthenium growing near the field border seem to be due to its higher total phenolic contents $\left(6678.2 \mathrm{mg} \mathrm{L}^{-1}\right)$, higher EC $\left(9.89 \mathrm{dSm}^{-1}\right)$ and lower osmotic potential $(-0.36 \mathrm{MPa})$ as well as complex interactions of a large number of phenolic compounds, namely gallic acid $\left(7.5 \mathrm{mg} \mathrm{L}^{-1}\right)$, caffeic acid (12.9 $\left.\mathrm{mg} \mathrm{L}^{-1}\right), 4$ hydroxy-3-methoxy benzoic acid $\left(37.1 \mathrm{mg} \mathrm{L}^{-1}\right)$ and p-coumaric acid (9.4 $\mathrm{mg} \mathrm{L}^{-1}$ ) (Tables 1 and 2). 
In summary, aqueous extracts of root, stem, leaf, fruit and whole plant parts of parthenium and its rhizospheric soils showed inhibitory effects on germination and seedling growth of maize to varied degrees. However, leaf extract of parthenium plant uprooted from the farm location near the field border while rhizospheric soil underneath parthenium growing near a water channel were to be more phytotoxic against maize. The same extracts were also found to contain the highest total phenolic contents, as well as broader range of phenolic compounds, showing a possible involvement of their complex interaction in causing phytotoxicity in maize.

\section{ACKNOWLEDGMENT}

This study is a part of the main author's thesis research work for a Ph.D. degree at the Department of Agronomy, University of Agriculture, Faisalabad, Pakistan. Authors of this study greatly acknowledge Dr. Razia Riaz, Research Officer, Hi Tech Laboratory, University of Agriculture, Faisalabad, Pakistan for his kind cooperation in providing facilities for HPLC studies.

\section{LITERATURE CITED}

AMBIYE, N.; GOLATKAR, V. Phytochemical analysis of Lantana camara and Parthenium hysterophorus.

BIOINFOLET, v. 7, n. 2, p. 135-136, 2010.

BATISH, D. R. et al. Phytotoxic effect of Parthenium residues on the selected soil properties and growth of chickpea and radish. Weed Biol. Manag., v. 2, n. 2, p. 73-78, 2002.

BATISH, D. R. et al. Assessment of parthenin against some weeds. Zeitschrift fürNaturforschung, v. 62, n. 5-6, p.367-372, 2007.

BELZ, R. G. Allelopathy in crop/ weed interactions - an update. Pest Manag. Sci., v. 63, v. 4, p. 308-326, 2007.

BERTIN, C. et al. The role of root exudates and allelochemicals in the rhizosphere. Plant Soil, v. 256, n. 1, p. 67-83, 2003.

DEVI, O. I.; DUTTA, B. K. Allelopathic effect of aqueous extract of Parthenium hysterophorus and Chromolaena odorata on the seed germination and seedling vigour of Zea mays L. In vitro. Acad. J. Plant Sci., v. 5, n. 4, p. 110-113, 2012.

Planta Daninha, Viçosa-MG, v. 32, n. 2, p. 243-253, 2014
DHOLE, J. A. et al. Allelopathic effect of aqueous leaf extract of Parthenium hysterophorus L. on seed germination and seedling emergence of some cultivated crops. J. Res. Biol., v. 1, n. 2 , p. 15-18, 2011.

FAROOQ, M. et al. Thermal hardening: a new seed vigor enhancement tool in rice. Acta Bot. Sinica, v. 47, n. 2, p. 187-193, 2005.

GLOBAL INVASIVE SPECIES DATABASE - GISD. Online data sheet. Parthenium hysterophorus (herb). (www.issg.org/ database), 2010.

HOFFMAN, M. L. et al. Allelopathic influence of germinating seeds and seedlings of cover crops on weed species. Weed Sci., v. 44, n. 3, p. 579-584, 1996.

HUSSAIN, F.; GADOON, M. A. Allelopathic effects of Sorghum vulgare. Pers. Oecologia, v. 51, n. 2, p. 284-288, 1981.

INDERJIT; CALLAWAY, R. M. Experimental designs for the study of allelopathy. Plant Soil, v. 256, n. 1, p. 1-11, 2003.

KOBAYASHI, K. Factors affecting phytotoxic activity of allelochemicals in soil. Weed Biol. Manag., v. 4, n. 1, p. 1-7, 2004.

INVASIVE SPECIES DEFINITION CLARIFICATION ISAC. Invasive species definition clarification and guidance white paper. 2006. Submitted by the Definitions Subcommittee of the Invasive Species Advisory Committee (ISAC). <www.pwsrcac.org/docs/d0040100.pdf>.

KHAN, N. et al. Assessment of allelopathic effects of parthenium (Parthenium hysterophorus L.) plant parts on seed germination and seedling growth of wheat (Triticum aestivum L.) cultivars. Pak. J. Weed Sci. Res., v. 18, n. 1, p. 39-50, 2012.

KOHLI, R. K.; RANI, D. Parthenium hysterophorus L. a review. Res. Bul. (Science) Pb. Univ., v. 44, n. 1/4, p. 105149, 1994.

SCOTT, S. J. et al. Review of data analysis methods for seed germination. Crop Sci., v. 24, n. 6, p. 1192-1199, 1984.

WESTON L. A. et al. Mechanisms for cellular transport and release of allelochemicals from plant roots into the rhizosphere. J. Exper. Bot., v. 63, n. 9, p. 3445-3454, 2012.

MAHARJAN, S. et al. Allelopathic effects of aqueous extract of leaves of Parthenium hysterophorus L. on seed germination and seedling growth of some cultivated and wild herbaceous species. Sci. World, v. 5, n. 5, p. 33-39, 2007.

MARWAT, K. B. et al. Parthenium hysterophorus L. a potential source of bioherbicide. Pak. J. Bot., v. 40, n. 5, p. 1933-1942, 2008. 
MERSIE, W.; SINGH, M. Allelopathic effect of parthenium (Parthenium hysterophorus L.) extract and residue on some agronomic crops and weeds. J. Chem. Ecol., v. 13, n. 7, p. 1739-1747, 1987.

MORADIDEZFULI, P. et al. Influence of priming techniques on seed germination behavior of maize inbred lines (Zea mays L.). ARPN J. Agric. Biol. Sci., v. 3, n. 3, p. 22-25, 2008.

NIGATU, L. et al. Impact of Parthenium hysterophorus on grazing land communities in north-eastern Ethiopia. Weed Biol. Manag., v. 10, n. 3, p. 143-152, 2010.

ORCHARD, T. Estimating the parameters of plant seedling emergence. Seed Sci. Technol., v. 5, n. 1, p. 61-69, 1977.

PAUDEL, V. R. et al. Effect of diffusates of Parthenium hysterophorous $\mathrm{L}$. on seed germination of raphanus sativus $\mathrm{L}$. Sci. World, v. 7, n. 7, p. 29-32, 2009.

PENG, S. L. et al. Mechanism and active variety of allelochemicals. Acta Bot. Sinica, v. 46, n. 7, p. 757-766, 2004.

PUTNAM, A. R. Allelopathic chemicals. Chem. Eng News, v. 61, n. 19, p. $34-43,1983$.

RANDHIR, R.; SHETTY, K. Developmental stimulation of total phenolics and related antioxidant activity in light and dark germinated maize by natural elicitors. Process

Biochem., v. 40, n. 5, p. 1721-1732, 2005.

REINHARDT, C. F. et al. Role of the allelochemical parthenin in the invasive strategy of the alien plant Parthenium hysterophorus L. South Afr. J. Bot., v. 75, n. 2, p. 417-418, 2009.

RIAZ, T.; JAVAID A. Prevalence of invasive parthenium weed in district Hafizabad, Pakistan. J. An. Plant Sci., v. 20, n. 2, p. $90-93,2010$.
RICE, E. L. Allelopathy - an update. Bot. Rev., v. 45, n. 1, p. 15-109, 1979.

RUAN, S. et al. The influence of priming on germination of rice (Oryza sativa L.) seeds and seedling emergence and performance in flooded soils. Seed Sci. Technol., v. 30, n 1, p. 61-67, 2002.

SINGH, H. P. et al. Phytotoxic effects of Parthenium hysterophorus residues on three Brassica species. Weed Biol. Manag., v. 5, n. 3, p. 105-109, 2005.

STEEGHS, M. et al. Proton-transfer-reaction mass spectrometry (PTR-MS) as a new tool for real time analysis of root-secreted volatile organic compounds (VOCs) in Arabidopsis thaliana. Plant Physiol., v. 135, n. 1, p. 47-58, 2004.

STEEL, R. G. D. et al. Principles and procedures of statistics. A Biometrical Approach. 3.ed. New York: McGraw Hill Book, 1996. 672 p.

VIDAL R. A. et al. Phenolics adsorption to soil reduces their allelochemical activity. Pesq. Agropec. Gaúcha, v. 4, n. 2, p. 125-129, 1998.

WAKJIRA, M. et al. Allelopathic effects of Parthenium hysterophorus extracts on seed germination and seedling growth of lettuce. Trop. Sci., v. 45, n. 4, p. 159-162, 2005.

WU, H. et al. Evaluation of seedling allelopathy in 453 wheat (Triticum aestivum) accessions against annual ryegrass (Lolium rigidum) by the equal-compartment-agar method. Austr. J. Agri. Res., v. 51, n. 7, p. 937-944, 2009.

ZIMDAHL, R. L. Fundamentals of weed science. 3.ed. London: Academic Press, 2007. 666 p. 